\section{Conservation practice establishment in two northeast lowa watersheds: Strategies, water quality implications, and lessons learned}

P.W. Gassman, J.A. Tisl, E.A. Palas, C.L. Fields, T.M. Isenhart, K.E. Schilling, C.F. Wolter, L.S. Seigley, and M.J. Helmers

\begin{abstract}
Coldwater trout streams are important natural resources in northeast Iowa. Extensive efforts have been made by state and federal agencies to protect and improve water quality in northeast Iowa streams that include Sny Magill Creek and Bloody Run Creek, which are located in Clayton County. A series of three water quality projects were implemented in Sny Magill Creek watershed during 1988 to 1999, which were supported by multiple agencies and focused on best management practice (BMP) adoption. Water quality monitoring was performed during 1992 to 2001 to assess the impact of these installed BMPs in the Sny Magill Creek watershed using a paired watershed approach, where the Bloody Run Creek watershed served as the control. Conservation practice adoption still occurred in the Bloody Run Creek watershed during the 10-year monitoring project and accelerated after the project ended, when a multiagency supported water quality project was implemented during 2002 to 2007. Statistical analysis of the paired watershed results using a pre/post model indicated that discharge increased $8 \%$ in Sny Magill Creek watershed relative to the Bloody Run Creek watershed, turbidity declined $41 \%$, total suspended sediment declined $7 \%$, and $\mathrm{NO}_{\mathrm{x}}-\mathrm{N}$ (nitrate-nitrogen plus nitrite-nitrogen) increased $15 \%$. Similar results were obtained with a gradual change statistical model. The weak sediment reductions and increased $\mathrm{NO}_{\mathrm{x}}-\mathrm{N}$ levels were both unexpected and indicate that dynamics between adopted BMPs and stream systems need to be better understood. Fish surveys indicate that conditions for supporting trout fisheries have improved in both streams. Important lessons to be taken from the overall study include (1) committed project coordinators, agency collaborators, and landowners/producers are all needed for successful water quality projects; (2) smaller watershed areas should be used in paired studies; (3) reductions in stream discharge may be required in these systems in order for significant sediment load decreases to occur; (4) long-term monitoring on the order of decades can be required to detect meaningful changes in water quality in response to BMP implementation; and (5) all consequences of specific BMPs need to be considered when considering strategies for watershed protection.
\end{abstract}

Key words: coldwater trout streams-Conservation Effects Assessment Project (CEAP) conservation practices — cost-share funding — paired watershed study — water quality

\begin{abstract}
Cold-water streams have been a key water resource in northeast lowa since the settlement of the state and support a variety of recreational opportunities, including trout fisheries. According to Kalishek (2005), it is not clear which Iowa streams sustained trout prior to European settlement. However, Kalishek notes comments recorded by biologist Seth Meek, indicating that trout
\end{abstract}

fisheries were already in decline in the 1890 s and that trout could no longer be caught in some streams such as the upper Iowa River. He further quotes Meek as stating: "The breaking of the native sod for agricultural purposes has especially affected the smaller streams in this respect, while the construction of ditches and the practice of underdraining have had their effects upon the larger ones.
Moreover the constant loosening of the soil, in farming, tends to reduce it to that condition in which it is readily transported by the heavy rains to produce muddy currents. To this cause, no doubt, is due the present absence of trout from many of the streams of northeastern Iowa and their marked decrease in other parts of the State."

The desire to maintain trout fishing resulted in the state of Iowa initiating stocking of brown (Salmo trutta) and rainbow trout (Oncorhynchus mykiss) in the late 1800s to replace declining populations of brook trout (Salvelinus fontinalis), which were the only species native to the state (IDNR 2007). This stocking program has been maintained to the present time, which now serves over 100 coldwater streams in 10 northeastern Iowa counties with rainbow and/or brook trout produced at three Iowa Department of Natural Resources (IDNR) facilities. An additional key goal of the overall IDNR trout fisheries program is to develop natural trout reproduction in northeast Iowa coldwater streams (primarily for brown trout). Only six Iowa streams supported natural reproduction in 1980 due primarily to sediment and other nonpoint source pollution that eliminated clean water and spawning beds in most of the streams (IDNR 2007). However, a concentrated effort focused on mitigating nonpoint source pollution, especially sediment loss from upland landscapes, has resulted in documented natural trout reproduction in 32 streams as of 2007 .

Philip W. Gassman is an associate scientist with the Center of Agricultural and Rural Development, Department of Economics, lowa State University, Ames, lowa. Jeff A. Tisl is a regional coordinator with the lowa Department of Agriculture and Land Stewardship, Division of Soil Conservation, West Union, lowa. Eric A. Palas is an environmental specialist with the lowa Department of Agriculture and Land Stewardship, Division of Soil Conservation, Elkader, lowa. Chad L. Fields is a research geologist, Keith E. Schilling is a research geologist, Calvin F. Wolter is a geographic information system analyst, and Lynette S. Seigley is a research geologist with the lowa Department of Natural Resources, Geological and Water Survey, lowa City, lowa. Thomas $M$. Isenhart is an associate professor in the Department of Natural Resource Ecology and Management, lowa State University, Ames, lowa. Matthew J. Helmers is an associate professor with the Department of Agricultural and Biosystems Engineering, lowa State University, Ames, lowa. 
A variety of conservation practice approaches have been used to address nonpoint source pollution in northeast Iowa coldwater stream systems, including establishment of Conservation Reserve Program (CRP) grassland, streambank stabilization, nutrient management practices, exclusion of livestock from streams, use of mulch and no-tillage systems, and establishment of conservation buffers, grassed waterways, terraces, and other structural or cropping system management practices. Examples of this multipronged conservation approach are the Sny Magill Creek watershed (SMCW) and Bloody Run Creek watershed (BRCW) located in Clayton County, Iowa, both of which support popular trout fishing resources managed by the IDNR. Extensive installation of conservation practices in the SMCW was carried out primarily during the 1990s as part of a paired watershed study in which the BRCW was assumed to be the control watershed (Fields et al. 2005). Water quality monitoring data were collected at multiple sites in both watersheds during the period of 1991 to 2001 as part of the study (USEPA 2009; Lombardo et al. 2000). Promotion of conservation practices accelerated in 2002 in the BRCW, resulting in expanded adoption of structural and other conservation practices over a five-year period similar to what had occurred previously in the SMCW. Water quality monitoring data are not available for this later period for either watershed; however, fish survey and other anecdotal information provide insights regarding water quality conditions.

The extensive establishment of conservation practices in both watersheds, coupled with intensive monitoring data collected during 1991 to 2001, provided an opportunity to evaluate the environmental impacts of conservation practices as part of a USDA Conservation Effects Assessment Project study for three watersheds representing three distinct landform regions in Iowa (Schilling et al. 2007). The Conservation Effects Assessment Project seeks to evaluate the effectiveness of different conservation practices in mitigating water quality problems in a variety of watershed conditions across the United States (Richardson et al. 2008; Duriancik et al. 2008; USDA NRCS 2008). The overall goal of this study was to synthesize key conservation practice strategies and water quality impacts in the SMCW and BRCW to support efforts within the con-

\section{Figure 1}

Distribution of land use in the Sny Magill Creek and Bloody Run Creek watersheds between 1991 and 2005 and location of monitoring sites for the 1992 to 2001 water quality study. (Data for the Sny Magill Creek watershed are from C. Kiepe, private consultant, Hampton, lowa, personal communication, 2005. Bloody Run Creek watershed data were collected in support of the water quality project conducted during 2002 to 2007 ).

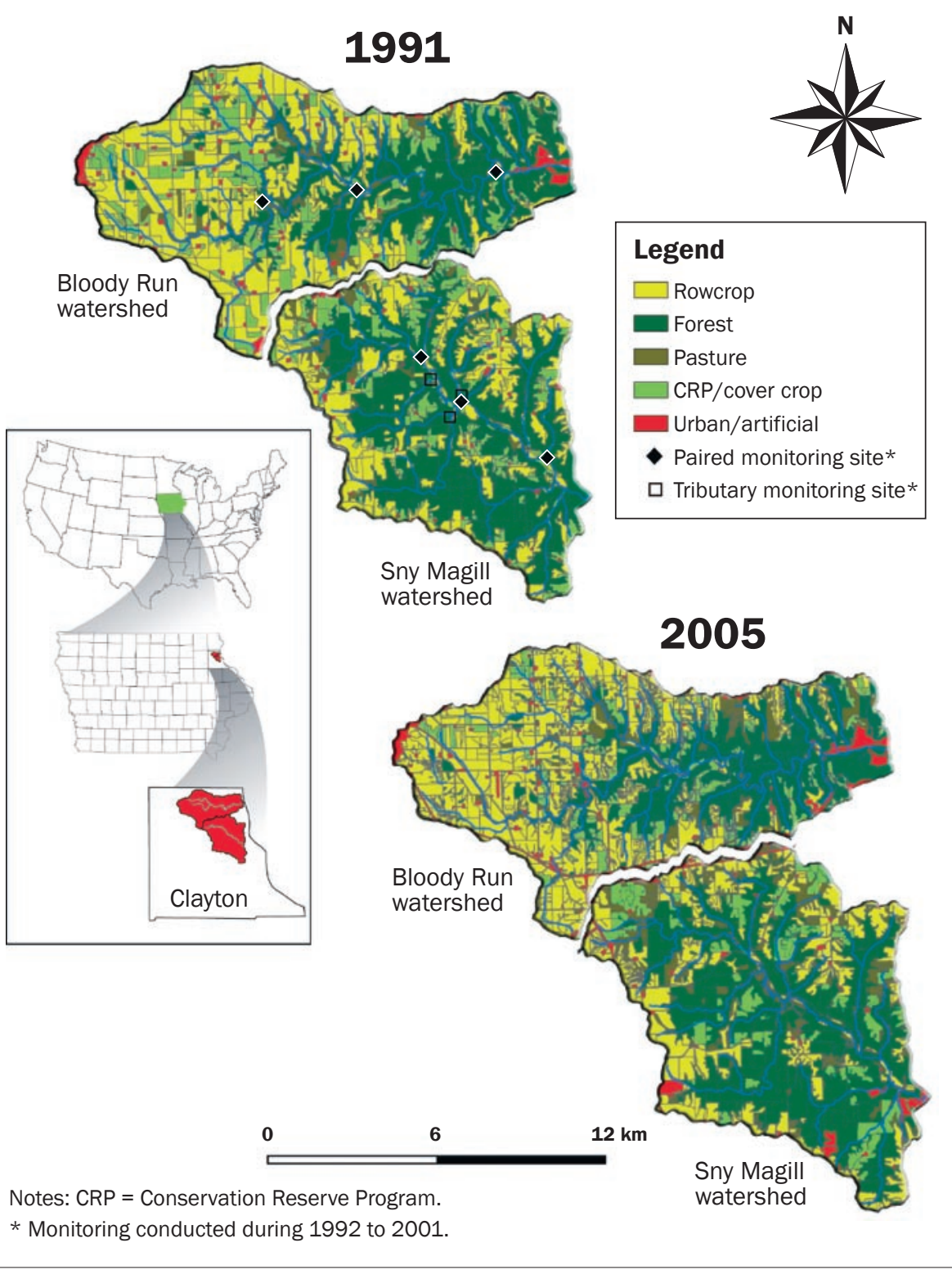

text of the Conservation Effects Assessment Project to effectively target conservation practices. Specifically, the objectives were to (1) document conservation practice establishment within the SMCW and BRCW, (2) assess the impacts of practice establishment on water quality and trout habitat and reproduction, and (3) summarize the lessons learned from the conservation initiatives in the two watersheds for application in future conservation targeting efforts in other watersheds.

\section{Materials and Methods}

Description of the Sny Magill Creek and Bloody Run Creek Watersheds. The SMCW and BRCW cover 9,126 ha $(22,542$ ac) and 9,804 ha $(24,216 \mathrm{ac})$, respectively, and are both located in Clayton County, Iowa (figure 1) within the Paleozoic Plateau/ Coulee Section Level IV Ecoregion (52b). This ecoregion is characterized by bedrockdominated terrain with steep slopes and bluffs, high relief, entrenched valleys, and cool waters with high gradients (Griffith et 


\section{Table 1}

Summary of 1991 and 2005 Sny Magill Creek watershed (SMCW) and Bloody Run Creek watershed (BRCW) land use.

\begin{tabular}{lrrrr}
\hline $\begin{array}{l}\text { Land-use } \\
\text { category }\end{array}$ & $\begin{array}{l}\text { 1991 SMCW } \\
\text { (ha) }\end{array}$ & $\begin{array}{l}\text { 2005 SMCW } \\
\text { (ha) }\end{array}$ & $\begin{array}{l}\text { 1991 BRCW } \\
\text { (ha) }\end{array}$ & $\begin{array}{l}\text { 2005 BRCW } \\
\text { (ha) }\end{array}$ \\
\hline CRP/cover crop & 1,471 & 1,467 & 1,885 & 1,295 \\
Urban artificial & 120 & 428 & 312 & 685 \\
Forest & 4,562 & 4,477 & 2,941 & 2,896 \\
Pasture & 331 & 446 & 493 & 574 \\
Row crops & 2,737 & 2,404 & 4,174 & 4,356 \\
\hline
\end{tabular}

Notes: CRP = Conservation Reserve Program. Data for the Sny Magill Creek watershed are from C. Kiepe, private consultant, personal communication, 2005, Hampton, lowa, . The Bloody Run Creek watershed data were collected in support of water quality project conducted during 2002 to 2007.

al. 1994). Both streams drain directly into the Mississippi River, with extensive relief of $155 \mathrm{~m}(509 \mathrm{ft})$ and $167 \mathrm{~m}$ (548 ft) occurring between the SMCW and BRCW upland areas and their respective outlets (Fields et al. 2005). The dominant soil associations in the watersheds are Downs-Fayette and FayetteNordness-Rock, which are characterized by steep slopes typically ranging between $9 \%$ to $14 \%$ (D slopes) and some even steeper slopes (E and F slopes). Over 50\% of the SMCW is classified as highly erodible land (HEL) (Fields et al. 2005), while nearly 100\% of the BRCW cropland is categorized as HEL (Palas 2007). Mean annual (during 1990 to 2008) precipitation of $914.4 \mathrm{~mm}$ (36 in) and temperature of $9^{\circ} \mathrm{C}\left(48^{\circ} \mathrm{F}\right)$ were recorded at Prairie du Chien, Wisconsin, which is located across the Mississippi River in close proximity to both watersheds.

Karst features (caves, sinkholes, and springs) are common in the Cambrian and Ordovician sandstone and limestone units in both watersheds (Fields et al. 2005). Due to the geologic conditions, approximately $85 \%$ of the annual stream flow of both creeks is attributable to baseflow, which is much higher than most Iowa streams and results in "cold water" conditions. Both Sny Magill Creek and Bloody Run Creek are managed as "put and take" trout fisheries by the IDNR, as well as North Cedar Creek, the main tributary of Sny Magill Creek.

Livestock production has decreased in both watersheds over the past two decades. It was estimated that at least 36 operations had livestock in the BRCW in 2002, with a distribution of 1,100 dairy cows, 1,400 feeder cattle, 600 pairs of cow/calves, 6,000 hogs, and 60 sheep (Palas 2007); livestock production was likely similar in the SMCW. By 2005 , row crop production had increased in the BRCW and had decreased slightly in the SMCW, as discussed in the LandUse Tracking section in this paper. Eroded sediment from agricultural lands was identified as the primary source of water quality impairment in the SMCW at the start of the water quality monitoring in 1991 (Fields et al. 2005). Nutrient and pesticide losses to the stream system were considered a secondary source of impairment. Water quality impairment issues were similar for the BRCW.

Land-Use Tracking. The distribution of land use in the two watersheds is shown for 1991 and 2005 in figure 1 and table 1. The 1991 SMCW land-use data is based on satellite imagery obtained at the start of the SMCW water quality project, while the 2005 SMCW land-use data was obtained via a field-level survey (C. Kiepe. Personal communication, 2005. Private consultant, Hampton, Iowa). The 2005 BRCW land-use data was derived from survey information collected in support of the Bloody Run Creek Water Quality Project. Dominant land-use categories in the SMCW are forest (49\%) and row crop (26\%); in the BRCW, $44 \%$ of the land area is in row crop, and 30\% is in forest. Notable land-use shifts between 1991 and 2005 include a decline of BRCW $\mathrm{CRP} /$ cover crop from $19 \%$ to $13 \%$, an increase of urban/artificial land use from 1\% to $5 \%$ in the SMCW and $3 \%$ to $7 \%$ in the BRCW, and a decline in SMCW row crop area from $30 \%$ to $26 \%$. Soybean plantings increased greatly in both watersheds during the 1990s due to a combination of increasing soybean prices and changes in federal legislation, especially modified rules enacted in the 1996 Federal Agriculture Improvement and Reform Act (Babcock et al. 1998).

Sny Magill Creek Watershed Water Quality Projects. Three separate projects were carried out from 1988 to 2000 to improve water quality in the SMCW
(Tisl and Palas 1998). These projects were carried out between 1988 and 1998 via interagency initiatives that included the IDNR, Iowa Department of Agriculture, and Land Stewardship (IDALS) Division of Soil Conservation (DSC), Iowa State University Extension, Clayton Soil and Water Conservation District (SWCD), and the USDA Natural Resources Conservation Service (NRCS). The 1988 to 1994 North Cedar Creek Project was supported by USDA cost-share funding and focused solely on the 1,304 ha $(3,221 \mathrm{ac})$ North Cedar Creek subwatershed, which was designated as an Iowa high quality waterway in 1989. The Sny Magill Hydrologic Unit Area (HUA) Project then provided the USDA with incentive funding for BMP implementation, technical assistance, and educational programs throughout the rest of the SMCW during 1991 to 1994. In 1994, the Sny Magill Creek Watershed Project was initiated, which replaced incentive funding lost from the HUA project. The SMCW Project was supported by US Environmental Protection Agency (USEPA) Section 319 funds administered by the IDNR and additional IDALS-DSC support. These funding sources were available through 1999. A total of nearly $\$ 3.4$ million was invested into staff support, cost share, monitoring, and demonstration and education efforts across the duration of the projects (Tisl and Palas 1998), with approximately $\$ 950,000$ devoted to cost-share funding and over $\$ 222,000$ more contributed by landowners/producers.

One of the major overall goals of the projects was to reduce sediment delivery by $50 \%$ to the SMCW stream system (Tisl and Palas 1998). Other key goals included reduction of nutrient losses from cropland through increased adoption of livestock manure storage systems and improved manure management and cropping practices and educational outreach to SMCW producers and the local public.

Significant adoption of conservation practices had occurred in the SMCW prior to these concentrated initiatives, especially in the form of reduced tillage (crop residue management), contouring, and crop rotations with alfalfa or other close grown crops. However, average erosion rates were still estimated to be $26.9 \mathrm{t} \mathrm{ha}^{-1}$ (12 tn $\left.\mathrm{ac}^{-1}\right)$, which were considerably higher than the maximum goal of $11.2 \mathrm{t} \mathrm{ha}^{-1}\left(5 \mathrm{tn} \mathrm{ac} \mathrm{c}^{-1}\right)$ set by the Clayton SWCD. Thus a targeted approach 
Table 2

Cumulative percent of best management practices completed per year during the Sny Magill Creek Watershed Monitoring Project time period.

\begin{tabular}{|c|c|c|c|c|c|c|c|c|}
\hline Year & $\begin{array}{l}\text { Terrace } \\
(\%)\end{array}$ & $\begin{array}{l}\text { Bank } \\
\text { protection } \\
\text { (\%) }\end{array}$ & $\begin{array}{l}\text { Water and } \\
\text { sediment } \\
\text { control basins } \\
(\%)\end{array}$ & $\begin{array}{l}\text { Drainage } \\
\text { tiles } \\
(\%)\end{array}$ & $\begin{array}{l}\text { Grade } \\
\text { stabilization } \\
\text { structures* } \\
(\%)\end{array}$ & $\begin{array}{l}\begin{array}{l}\text { Tree } \\
\text { planting } \\
\text { (\%) }\end{array} \\
\end{array}$ & $\begin{array}{l}\text { Field } \\
\text { border } \\
(\%) \\
\end{array}$ & $\begin{array}{l}\text { Contouring } \\
(\%)\end{array}$ \\
\hline 1993 & 40 & 0 & 34 & 38 & 92 & 20 & 35 & 12 \\
\hline 1994 & 59 & 0 & 52 & 56 & 92 & 20 & 94 & 44 \\
\hline 1997 & 88 & 57 & 95 & 87 & 98 & 40 & 100 & 98 \\
\hline 1998 & 95 & 100 & 98 & 94 & 100 & 100 & 100 & 100 \\
\hline 1999 & 96 & 100 & 100 & 95 & 100 & 100 & 100 & 100 \\
\hline 2000 & 99 & 100 & 100 & 98 & 100 & 100 & 100 & 100 \\
\hline 2001 & 100 & 100 & 100 & 100 & 100 & 100 & 100 & 100 \\
\hline
\end{tabular}

Note: Data for table 2 are from C. Fields (2004).

* Many of the structures that were installed prior to 1993 were defined as grade stabilization structures, when in fact they should have been categorized as water and sediment control basins. The true distribution of these structures is likely more on the order of 120 water and sediment control basins and 31 grade stabilization structures. The general effect is similar for both practices, although the water and sediment control basins typically impact a considerably larger area.

was implemented by Clayton SWCD personnel and cooperating agencies designed to install conservation practices in vulnerable locations, in the most cost-effective manner possible. Particular weight was given to crop fields located near streams that could potentially contribute greater sediment loads (and other pollutants) to Sny Magill Creek and tributaries. The targeting process for the SMCW water quality projects was further aided by using a relatively simplistic sediment delivery tracking tool created by the USDA NRCS in 1994 (USDA NRCS 1998), which interfaced USDA Universal Soil Loss Equation (USLE) (Wischmeier and Smith 1978) erosion estimates with sediment delivery estimates.

The focused conservation efforts in these three projects resulted in greatly expanded adoption of a variety of best management practices (BMPs) over the 11-year span of 1988 to 1998 in the SMCW. Participation rates in the watershed were very high; $81 \%$ of the 98 landowners identified in the watershed participated in the North Cedar Creek Project and Sny Magill HUA Project (Tisl and Palas 1998; Fields et al. 2005). Table 2 lists the cumulative percentages of key practices installed during the water quality monitoring project time period as well as the total units of each practice installed over the course of the three SMCW water quality projects. The total levels of BMPs implemented through the Sny Magill HUA Project and SMCW Project included over 82,000 m (268,900 ft)

\section{Figure 2}

Crop fields identified as being treated with one or more conservation practices in the 2005 field-level survey are shown (land parcels treated with grade stabilization structures or water and sediment control basins are not shown). The not applicable areas identify land tracts managed as forest or grassland. (Data are from C. Kiepe, private consultant, Hampton, lowa, personal communication, 2005).

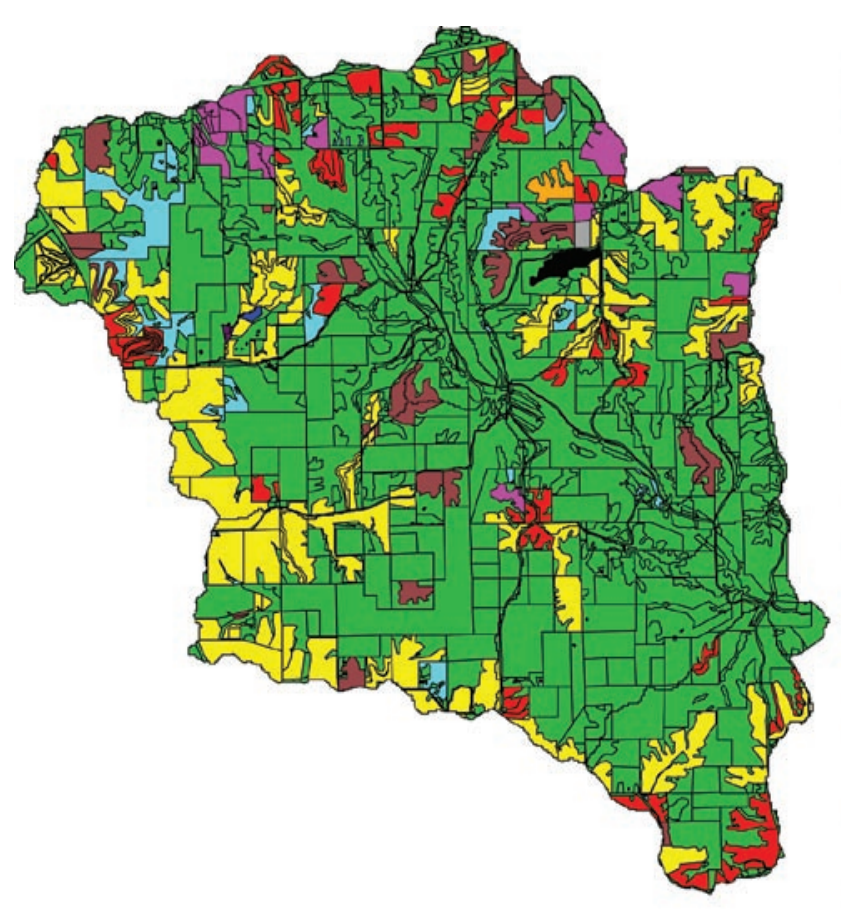


of terraces, nearly 49,000 m (161,000 ft) of associated artificial subsurface drainage, 347 $\mathrm{m}(1,138 \mathrm{ft})$ of streambank protection, over $8,000 \mathrm{~m}(26,200 \mathrm{ft})$ of field borders, and 722 ha $(1,783 \mathrm{ac})$ of contouring. Over 150 water and sediment control basins and grade stabilizations structures were also installed during the course of the projects (table 2), although some of these were incorrectly accounted for in the early phases of the overall project (see table 2 footnote).

The efforts to promote greater use of manure management systems lost momentum during the course of the projects, due primarily to a dramatic decrease in dairy operations, additional losses of beef cattle operations, and a concentration of hog production on fewer operations (Tisl and Palas 1998). However, survey data collected for the SMCW and surrounding areas near the end of the overall project indicated that a high percentage of producers had reduced nitrogen fertilizer use due to enhanced recognition of manure or legume crop nitrogen contributions. Establishment of other conservation practices also occurred as described by Tisl and Palas (1998).

The 2005 field-level survey showed that increased terrace installation has occurred since completion of the SMCW water quality project (Schilling et al. 2007) and verified the extensive treatment of cropland parcels with contouring, terraces, contour buffers, field buffers, or combinations of two or more of these BMPs (figure 2). The 2005 survey also confirmed that virtually all of the crop fields were also managed with mulch tillage (30\% or greater residue cover) or no-till.

Bloody Run Creek Watershed. Subsequent intensive conservation practice efforts were focused on the BRCW during 2002 to 2007 and were led primarily by IDALS DSC and the Clayton SWCD (Palas 2007). Cost-share funding for the project was obtained from several sources. The primary support came from USEPA Section 319 funds administered by the IDNR and IDALS Water Protection Funds and Watershed Protection Funds. These funds were used for the majority of cost-share funding provided for installation of structural conservation practices such as terraces and grassed waterways. Additional cost-share support was received from other IDALs and USDA sources. Approximately $\$ 650,000$ of cost-share funds were allocated by the different agencies during the five-year project. Landowners/producers contributed

\section{Table 3}

Eligible practices, cost-share rates, and total completed units of each practice for the Bloody Run Watershed Project.

\begin{tabular}{lccc}
\hline Eligible practice & Cost share & Project goal & Total completed \\
\hline Terraces & $75 \%$ & $30,480 \mathrm{~m}$ & $65,500 \mathrm{~m}$ \\
Water and sediment control basins & $75 \%$ & 10 & 7 \\
Grade stabilization structures & $75 \%$ & 5 & 6 \\
Gassed waterways & $75 \%$ & $610 \mathrm{~m}$ & $2,669 \mathrm{~m}$ \\
Pasture management/planting & $\$ 30 / \$ 60 *$ & 81 ha & na \\
Timber stand improvement & $75 \%$ & $152 \mathrm{ha}$ & $94.5 \mathrm{ha}$ \\
Resource protection fencing & $75 \%$ & $610 \mathrm{~m}$ & $3,188 \mathrm{~m}$ \\
Animal waste management systems & $75 \%$ & 2 & na \\
Tree planting & $75 \%$ & $20.2 \mathrm{ha}$ & $6.1 \mathrm{ha}$ \\
Streambank protection & $75 \%$ & $305 \mathrm{~m}$ & $229 \mathrm{~m}$ \\
Nutrient management & $\$ 3 / \$ 2 / \$ 2 \dagger$ & 1,619 ha & na \\
Continuous CRP & $50 \%$ & $61 \mathrm{ha}$ & $23 \mathrm{ha}$ \\
\hline
\end{tabular}

Notes: CRP = Conservation Reserve Program. na = not applicable; this management practice was not implemented during the duration of the Bloody Run Watershed Project water quality project. Data are from Palas (2007).

* On a per-acre basis.

† On a per-acre basis over a three-year period; i.e, \$3 ac $\mathrm{ac}^{-1}$ during the first year, etc.

an additional $\$ 229,000$ towards completing conservation practice installation.

The overall goals for the project were similar to the previous SMCW efforts, including reduction of sediment delivery (by 33\%), improved fertilizer and manure application methods (on $50 \%$ of the cropland), promotion of stream corridor and sinkhole protection, implementation of more manure management systems, and increased demonstration and educational opportunities (Palas 2007). The Revised Universal Soil Loss Equation (RUSLE), described by Renard et al. (1997), was interfaced with the tracking tool used previously for the SMCW water quality project to estimate changes in gross sediment erosion occurring in the BRCW, both before and after the conservation practices were implemented during 2002 to 2007.

Approximately 60 landowners or farm operators were identified as "decision makers" at the start of the project, several of whom were well acquainted with the previous SMCW projects and quickly grasped the general objectives and opportunities of the BRCW Project. The use of conservation practices was also already well established; for example, it was estimated that over 143,000 m $(470,000 \mathrm{ft})$ of terraces had already been installed on about 1,130 ha $(2,800 \mathrm{ac})$ in the watershed, with most of those constructed in the 20 years prior to 2002 (with nearly 34,000 $\mathrm{m}[111,300 \mathrm{ft}]$ installed while the BRCW served as the "control watershed" for the SMCW monitoring project). The BRCW landowners and farm operators also proved as a whole to be very flexible during the course of the project, which suffered from instability and uncertainty at times regarding assurance of initially promised cost-share funds. As a result, particular emphasis was placed on funding conservation practices that could be planned and implemented quickly. In addition, priority was given to supporting practices that could reduce sediment losses on vulnerable landscapes, especially higher sloped cropland planted in corn and soybean rotations.

The overall impact of the BRCW Project is summarized in table 3 in terms of the originally eligible practices, amount of cost share provided for each prospective practice, the initial goals for total units of installed practices, and the final resulting units of installed practices (Palas 2007). Over 800 ha $(1,976$ ac) of cropland were treated with the new BMPs that were adopted during the fiveyear Bloody Run Watershed Project. Project goals for terraces and grassed waterways were greatly exceeded, underscoring the emphasis placed on installing practices on vulnerable landscapes and the need to utilize cost-share funds while they were available. Resource protection fencing also proved to be more popular than initially expected, while goals for water and sediment control basins, grade stabilization structures, timber stand improvement, tree planting, streambank protection, and continuous CRP were also partially or completely met. Establishment of additional buffers along portions of the stream system 
that is stocked with trout was accomplished, but the goal of buffering sinkholes did not gain traction during the project. Adoption of additional pasture management/planting, animal waste management systems, or enhanced nutrient management did not occur during the five-year project, due primarily to the extra planning, design, and/or implementation time commitments needed for these practices that could not be fulfilled due to the nature of the funding streams that occurred.

Monitoring Design. The SMCW and $\mathrm{BRCW}$ monitoring project was an interagency effort involving the IDNR, the University of Iowa Hygienic Laboratory, and the US Geological Survey and was performed during 1991 to 2001 in an effort to determine the impacts of BMP installation in the SMCW on water quality, stream habitat, fish, and benthic macroinvertebrates (Fields et al. 2005). A paired watershed study design that included three paired sites in the two watersheds was used for the monitoring project (figure 1) (Fields et al. 2005), which is the most appropriate monitoring design when assessing the impact of BMP systems at the watershed scale (Spooner et al. 1985). The paired watershed study design assumes that both watersheds included in the analysis will respond the same to environmental changes, even if the physical characteristics are not totally uniform, resulting in minimal environmental variation effects on the data (Clausen and Spooner 1993). The BRCW was designated as the control watershed due to its similar size, topography, soils, land use, hydrogeology, and other characteristics and because intensive BMP implementation projects were not supported in the BRCW during the monitoring period. (However, complete control of landowners' decisions was impossible during the study, and terraces and other BMPs were installed during this time).

The results described here focus primarily on selected key water quality indicators measured in the project: total suspended solids (TSS), turbidity, $\mathrm{NO}_{\mathrm{x}}-\mathrm{N}$ (nitrate-nitrogen plus nitrite-nitrogen), and total phosphorus (TP). Detailed methods and comprehensive results are reported by Fields et al. (2005). Only the paired monitoring results are described here, with the primary focus on the results for the paired downstream sites (SN1 and BR1). The discharge data collected at SN1 and BR1 were measured continuously and were aggregated to daily levels, whereas $\mathrm{NO}_{\mathrm{x}}-\mathrm{N}, \mathrm{TP}$, and turbidity samples were measured weekly; the pollutant indicators were sampled at generally similar rates at the upstream and tributary sites (figure 1). The TSS, $\mathrm{NO}_{\mathrm{x}}-\mathrm{N}$, and TP data are reported in typical concentration units of $\mathrm{mg}$ $\mathrm{L}^{-1}$. Turbidity water quality measurements are qualitative in nature, reflecting the amounts of both suspended and dissolved solids in a water sample rather than actual concentrations and are expressed in terms of nephelometric turbidity units (NTU). Detailed summaries of the monitoring results for individual water years are cited in Fields et al. (2005).

Paired Statistical Models. Two different statistical regression models were used to analyze the impacts of BMP implementation in the SMCW: the pre/post and gradual change models. Distinct pre-BMP calibration and post-BMP treatment periods are required to configure the pre/post model. In an ideal paired watershed project, a calibration period is established before BMP implementation is initiated in the treatment watershed (SMCW in this study). However, that option was not available when the monitoring started. Thus, water years 1992 to 1994 were selected as the pre-BMP calibration period to establish an adequate time period for a good relationship between the two streams and because the majority of the BMPs had not yet been installed in the SMCW. The post-BMP treatment period was assumed to be water years 1999 to 2001 because the major funding and corresponding conservation practice adoption ended in 1999. Calibration and treatment periods were not used in the gradual change model. Instead, the independent variable is based on units of time, which can be days, weeks, or months, depending on how frequently the water quality parameter was sampled.

The advantage of the pre/post model is that it allows a dataset to be divided into two distinct calibration and treatment time periods, which allows for detection of statistically significant trends. However, the lack of a true pre-BMP calibration period precluded taking full benefit of this pre/post model strength. Nevertheless, significant trends in water quality could be determined, assuming a lag time in the BMP effects would occur. In contrast, the gradual change model provided a truer analog of actual BMP adoption and associated environmental impacts in the monitoring project, due to the lack of restrictions in having to define specific calibration and treatment periods. Additional details regarding the structure of the statistical models, including issues regarding data normality, autocorrelation, and statistical sensitivity of the models, are described in more detail in Fields et al. (2005).

\section{Results and Discussion}

Erosion Reduction Estimates. The cumulative effects of the BMPs installed in the SMCW during 1991 to 1998 period of the water quality project were estimated by the USDA NRCS, using the previously described USLE-based sediment delivery tool, to result in cumulative $50 \%$ reduction in sediment loss as compared to the pre-BMP implementation period (Tisl and Palas 1998), which equaled approximately $3,900 \mathrm{t} \mathrm{y}^{-1}$

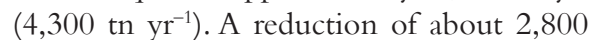

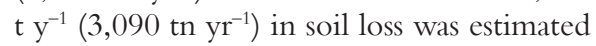
for the BRCW using the RUSLE-based sediment delivery model in response to the conservation practices installed during 2002 to 2007 as part of the water quality project (Palas 2007).

Discharge. Discharge measured at sites SN1 and BR1 proved highly correlated throughout the duration of the monitoring study (Coefficients of determination $\left.\left[r^{2}\right]=0.75 ; p<0.0001\right)$. The slope of the regression was 1.027; a slope approaching 1.0 indicates similar flow quantities in both streams. The daily SMCW discharge averaged $0.59 \mathrm{~m}^{3} \mathrm{~s}^{-1}\left(21.0 \mathrm{ft}^{3} \mathrm{sec}^{-1}\right)$, which was $15 \%$ lower than the corresponding BRCW average daily discharge of $0.7 \mathrm{~m}^{3} \mathrm{~s}^{-1}$ (24.8 $\left.\mathrm{ft}^{3} \sec ^{-1}\right)$. However, water yield was slightly higher for the SMCW as compared to the BRCW: $0.056 \mathrm{~m}^{3} \mathrm{~s}^{-1} \mathrm{~km}^{-2}\left(0.76 \mathrm{ft}^{3} \mathrm{sec}^{-1}\right.$ $\left.\mathrm{mi}^{-2}\right)$ versus $0.054 \mathrm{~m}^{3} \mathrm{~s}^{-1} \mathrm{~km}^{-2}\left(0.74 \mathrm{ft}^{3} \mathrm{sec}^{-1}\right.$ $\left.\mathrm{mi}^{-2}\right)$. The mean baseflow component of the overall streamflow was estimated to be $85 \%$ for the SMCW and $86 \%$ for the BRCW. As noted previously, these are very high relative to most Iowa streams.

The annual trends in discharge are shown in the boxplot graph in figure 3. The greatest annual median flows of $0.88 \mathrm{~m}^{3} \mathrm{~s}^{-1}\left(31 \mathrm{ft}^{3}\right.$ $\mathrm{sec}^{-1}$ ) for Sny Magill Creek and $0.99 \mathrm{~m}^{3} \mathrm{~s}^{-1}$ $\left(35 \mathrm{ft}^{3} \mathrm{sec}^{-1}\right)$ for Bloody Run Creek occurred in 1993, which was a year of record precipitation and flooding across much of Iowa and the upper Midwest. Discharge increases of $8 \%$ and $12 \%$ were predicted for sampling site SN1 with the pre/post and gradual change models, respectively. These predicted increases represent a shift of $0.6 \mathrm{~m}^{3} \mathrm{~s}^{-1}\left(21.2 \mathrm{ft}^{3} \mathrm{sec}^{-1}\right)$ in the calibration period to $0.65 \mathrm{~m}^{3} \mathrm{~s}^{-1}\left(22.9 \mathrm{ft}^{3}\right.$ 


\section{Figure 3}

Average daily discharge measured during 1992 to 2001 at the downstream site $\mathrm{SN}_{1}$ in the Sny Magill Creek watershed and the downstream site BR1 in the Bloody Run Creek watershed (data for this figure are from Fields et al. 2005).

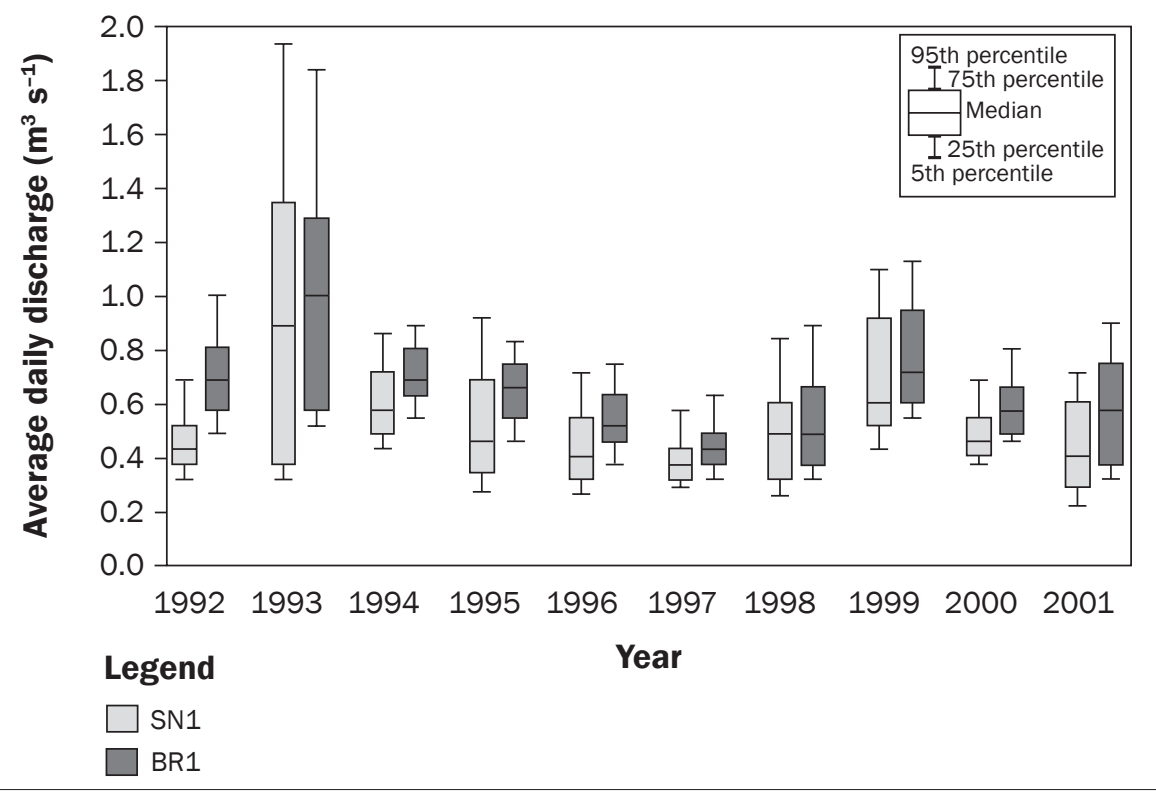

$\sec ^{-1}$ ) in the treatment period for the pre/post model, and a daily average increase of $0.48 \mathrm{~m}^{3}$ $\mathrm{s}^{-1}\left(16.8 \mathrm{ft}^{3} \mathrm{sec}^{-1}\right)$ to $0.53 \mathrm{~m}^{3} \mathrm{~s}^{-1}\left(18.8 \mathrm{ft}^{3} \mathrm{sec}^{-1}\right)$ in the gradual change model.

It is not clear why the Sny Magill discharge increased during the monitoring study. No significant change in cumulative precipitation was detected using multiple regression

\section{Figure 4}

Average monthly total suspended solids measured during 1992 to 2001 at the downstream site $\mathrm{SN}_{1}$ in the Sny Magill Creek watershed and the downstream BR1 in the Bloody Run Creek watershed (data for this figure are from Fields et al. 2005).

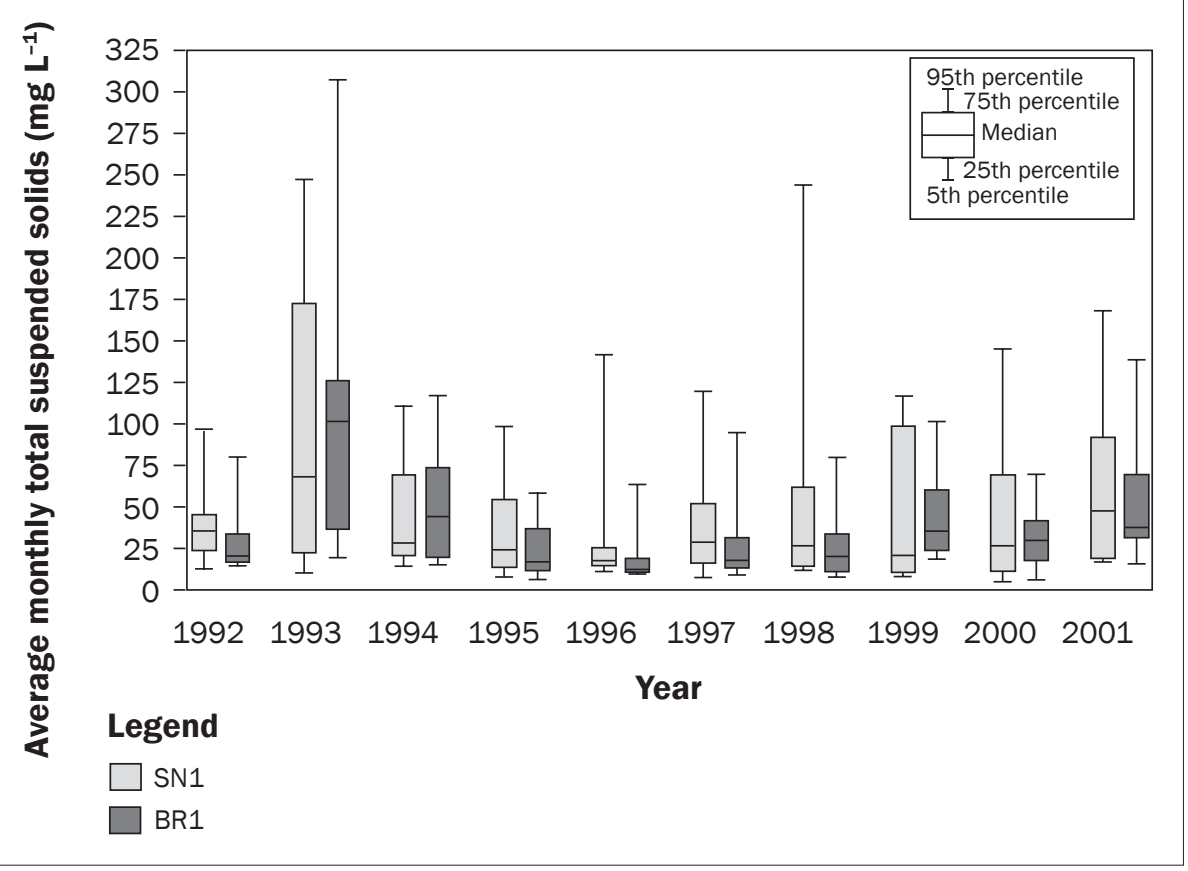

analysis, and hydrograph separation did not reveal any significant change in either baseflow or surface runoff. One possible source of the increased discharge is the large increase in terraces installed in the watershed, as discussed in more detail shortly.

Total Suspended Solids. Boxplots of annual measured TSS levels at SN1 and BR1 are shown in figure 4; these annual data are based on monthly means that were aggregated from the original raw data. The highest suspended sediment levels alternated from year-to-year between the two sites. The highest measured monthly median and overall levels for both sites were again recorded for 1993 - the year with the highest discharge levels. The TSS trends generally followed the discharge trends, with declines in measured TSS levels occurring in both watersheds from 1993 to 1996 followed by a gradual increase at both SN1 and BR1 for the remainder of the monitoring period (figure 4).

The pre/post model predicted a 7\% decline in TSS at site SN1 over the duration of the project, while the gradual change model prediction indicated no statistical change. These results were unexpected in light of the tremendous increase of conservation practices that had occurred in the SMCW and previous estimates that the installed practices would result in a $50 \%$ reduction of sediment delivered to the stream. Several factors likely account for this discrepancy, including long lag times for full BMP impacts and increased streambank and channel erosion. These and other related issues are further discussed.

Turbidity. Annual boxplots of turbidity are provided for sites SN1 and BR1 (figure 5). Turbidity measurements are very dependent on discharge; however, the turbidity levels plotted in figure 5 clearly followed a steady downward trend across the 10-year monitoring period for both sites. The SN1 median turbidity levels ranged from 8 to 9 NTU in 1992 and 1993 to less than 5 NTU in the last few years. These SN1 annual median turbidity levels were higher than the corresponding BR1 median values across virtually the entire sampling period. The only exceptions were the last two years when the BR1 values were slightly higher. Similar to discharge and sediment, the highest median values were recorded in 1993.

The pre/post and gradual change model predictions showed significant turbidity reductions at $\mathrm{SN} 1$ relative to $\mathrm{BR} 1$. The 


\section{Figure 5}

Turbidity levels measured during 1992 to 2001 at the downstream site SN1 in the Sny Magill Creek watershed and the downstream site BR1 in the Bloody Run Creek watershed (data for this figure are from Fields et al. 2005).

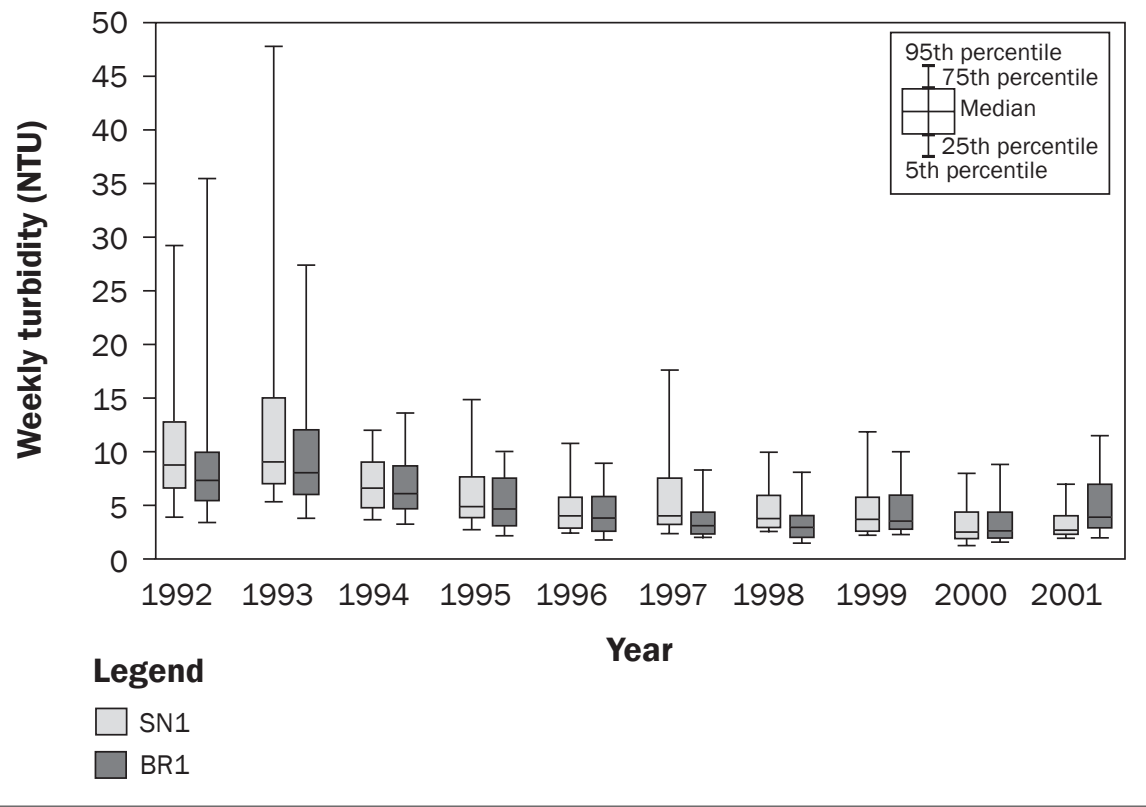

gradual change model suggested that turbidity decreased $40 \%$ at SN1, reflecting a decrease from $7.3 \mathrm{NTU}$ in the calibration period to $4.3 \mathrm{NTU}$ in the treatment period. The gradual change model predicted a $46 \%$ decrease in turbidity that equates to an over-

all decrease from 7.1 NTU to 3.9 NTU over the duration of the 10-year study period.

Explicit turbidity standards have not been established for coldwater streams, either by the State of Iowa or at the federal level. However, several states (e.g., Minnesota)

\section{Figure 6}

$\mathrm{NO}_{\mathrm{x}}-\mathrm{N}$ concentrations measured during 1992 to 2001 at the downstream site $\mathrm{SN}_{1}$ in the Sny Magill Creek watershed and the downstream site BR1 in the Bloody Run Creek watershed (data for this figure are from Fields et al. 2005).

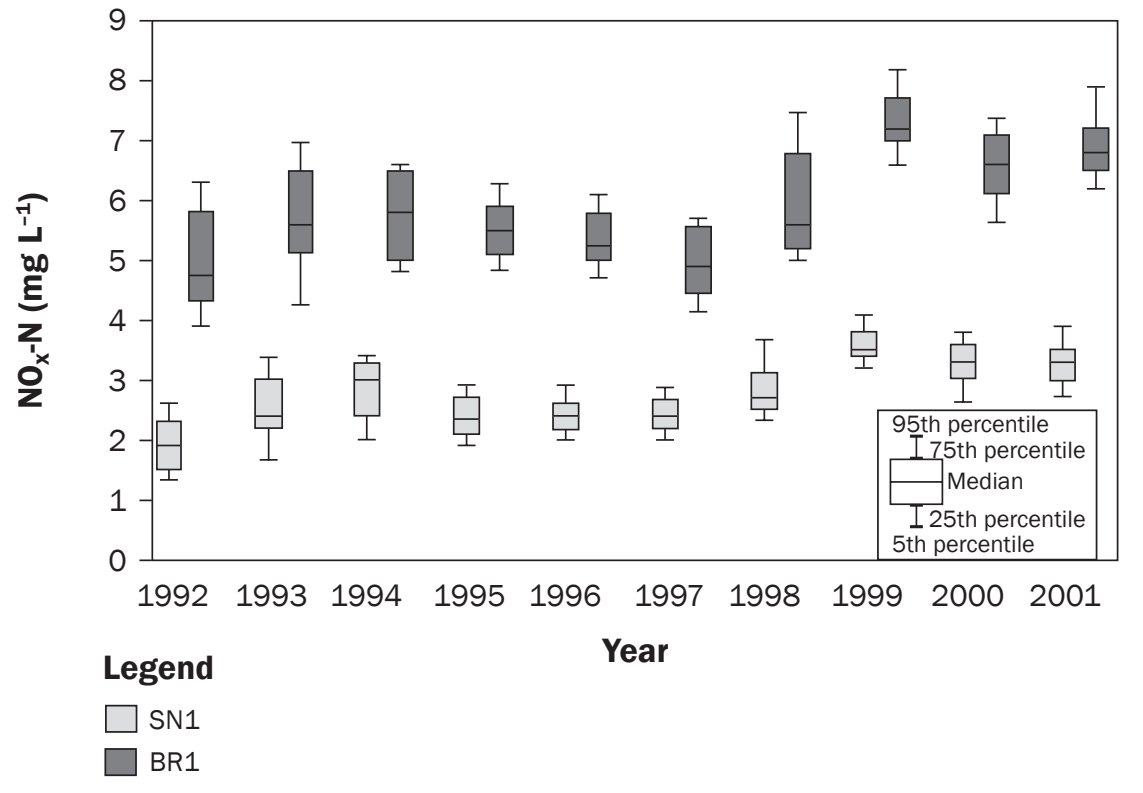

have set a standard of 10 NTU for coldwater streams. Median turbidity values sampled at both SN1 and BR1 never exceeded this level during the 10-year monitoring effort. This fact, coupled with the decrease that occurred during the study period, indicates a high degree of water clarity in both Sny Magill Creek and Bloody Run Creek. The results also indicate a decrease in some form of solids, which were not accounted for in the suspended sediment measurements but did affect the turbidity measurements. These were likely particles smaller than $45 \mu \mathrm{m}$ (0.0018 in) that are considered total dissolved solids, such as lighter-weight organics or colloidal-sized particles that can contribute to turbidity.

Nutrients. The median $\mathrm{NO}_{\mathrm{x}}-\mathrm{N}$ concentrations at SN1 ranged from $1.9 \mathrm{mg} \mathrm{L}^{-1}$ in 1992 to $3.5 \mathrm{mg} \mathrm{L}^{-1}$ in 1999 (figure 6). The lowest and highest median BR1 concentrations occurred in the same two years, ranging from $4.75 \mathrm{mg} \mathrm{L}^{-1}$ in 1992 to $7.2 \mathrm{mg}$ $\mathrm{L}^{-1}$ in 1999 . The pre/post model prediction indicated that the $\mathrm{NO}_{\mathrm{x}}-\mathrm{N}$ concentrations increased 15\% from 1992 to 2001 at SN1, based on calculated calibration and treatment concentrations of $2.7 \mathrm{mg} \mathrm{L}^{-1}$ and $3.1 \mathrm{mg}$ $\mathrm{L}^{-1}$, respectively. The gradual change model predicted a much larger $\mathrm{NO}_{\mathrm{x}}-\mathrm{N}$ concentration increase of $39 \%$ at SN1 in which the $\mathrm{NO}_{\mathrm{x}}-\mathrm{N}$ concentrations were determined to increase from $2.3 \mathrm{mg} \mathrm{L}^{-1}$ to $3.2 \mathrm{mg} \mathrm{L}^{-1}$. The increase in $\mathrm{NO}_{\mathrm{x}}-\mathrm{N}$ concentrations at SN1 was another unexpected result from the monitoring study. The underlying reason for this trend in increased $\mathrm{NO}_{\mathrm{x}}-\mathrm{N}$ levels is not immediately clear. One possible reason is that the large increase in tiled terraces may have more efficiently routed $\mathrm{NO}_{\mathrm{x}}-\mathrm{N}$ to the stream system. The extent of the groundwater capture zone is also not known for either watershed, and thus it is possible that $\mathrm{NO}_{\mathrm{x}}-\mathrm{N}$ could have been transported from outside the watersheds.

Total phosphorus concentrations measured over the duration of the monitoring study were typically lower than the detection limit and were continuously below the limit during 1996 to 1999 . This precluded performing statistical assessments with the pre/post and gradual change models. Median concentrations were also below the USEPA recommended level of $0.1 \mathrm{mg} \mathrm{L}^{-1}$ in each year except 1993.

Responses at Upstream Sites. Turbidity and nutrient responses at the upstream SN2 and $\mathrm{SN} 3$ sites sites (see locations in figure 1) 
were generally similar for those found at SN1, with predicted turbidity declines of $34 \%$ and $24 \%$ at SN2 based on the pre/post and gradual change models and estimated $\mathrm{NO}_{\mathrm{x}}-\mathrm{N}$ declines ranging from $26 \%$ to $43 \%$ at sites SN2 and SN3 using the two statistical models. In both watersheds, median concentrations measured at upstream sites were consistently higher than those measured at the watershed outlets. These spatial trends reflect the influence of land use on $\mathrm{NO}_{\mathrm{x}}-\mathrm{N}$ concentrations as row crop land cover is more prominent in the upper portion of the watersheds, while woodland and grassland are found in greater proportions in the lower reaches of the basins (figure 1). These trends likely also reflect instream loss of $\mathrm{NO}_{\mathrm{x}}-\mathrm{N}$ from assimilation and dentitrification. Additional details of these and other monitoring results are reported in Fields et al. (2005).

Fish Assessments and Other Water Quality Assessments. Other water quality information was gathered that provided insights on physical habitat characterization, physical habitat trends, benthic macroinvertebrates, and fish populations; these data are described in detail by Fields et al. (2005). In general, the physical habitat and benthic macroinvertebrate data gathered during the course of the monitoring project were inconclusive as to whether conditions for supporting trout had improved or degraded. Anecdotal information reported by Tisl and Palas (1998) suggest some evidence of improved conditions in Sny Magill Creek, specifically in regards to stream response to high precipitation events. It was noted that local producers began to notice that less flooding occurred in the main channel after rainfall events of 51 to $76 \mathrm{~mm}$ ( 2 to 3 in) and that high flows after such events were of less magnitude and shorter duration (half-day versus typically two- to three-day flooding events). Trout fishers also began to recognize that Sny Magill Creek returned to "clean conditions" faster than previously and that purging of increased suspended sediment in the stream occurred quicker than many other streams in the region.

Annual fish assessments, which were performed at five stream locations in the SMCW and at one stream site in the BRCW, provided further indicators of improved stream conditions. Fish Index of Biotic Integrity and fish richness studies indicated slight improvement at several SMCW sites. The slimy sculpin (Cottus cognatus) was also first found in 2001, which was a further positive development because this fish is classified as intolerant of environmental degradation and as a stenothermal cold water species (Lyons et al. 1996; Mundahl and Simon 1999). The slimy sculpin was the dominant fish species found at the Bloody Run Creek site during each annual assessment and accounted for $95 \%$ of the fish population during six of the ten years. Additional fish surveys were performed in 1999 and 2003 for Bloody Run Creek and in 2005 to 2007 for Sny Magill Creek (B. Kalishek, personal communication. Decorah Fish Hatchery, Iowa Department of Natural Resources, Decorah, Iowa). The Bloody Run Creek surveys showed that natural reproduction of brown trout had improved between the two years, especially in the lower segments of the stream, indicating that overall Bloody Run Creek stream conditions for sustaining trout fisheries had improved (Palas 2007). However, natural reproduction of brown trout has not been documented in Sny Magill Creek. The overall fish assessment survey results for both streams are encouraging and point to improving conditions for maintaining trout fisheries.

Lessons Learned. The water quality projects carried out in the SMCW and BRCW were in general quite successful, in spite of the fact that not all goals were met. Participation rates were very high across all the projects, and the landowners and producers demonstrated considerable commitment to conservation principles. This was consistent with historical patterns in the region, which has resulted in high levels of conservation practice adoption on cropland landscapes in both watersheds. However, the water quality impacts were not always consistent with expectations. A number of key insights can be gleaned from the water quality and monitoring projects described in this study; additional points are made in Tisl and Palas (1998), Fields et al. (2005), and Palas (2007).

An overarching lesson was the need for cooperative and committed efforts by all groups engaged in the water quality projects. Unexpected funding instability was encountered in the water quality projects established in both watersheds. Committed action by project coordinators, the willingness of partnering agencies to consider other funding options, and the flexibility of landowners and producers all proved vital to securing needed resources to continue the projects and achieve the overall desired impacts of each project.

The need for maintaining landowner/producer interest was also essential for achieving successful water quality projects. Cost-share funding was critical in generating landowner/ producer interest in conservation practices. Interest levels always exceeded available costshare funds for the Bloody Run Creek Water Quality Project (Palas 2007). It was noted for the SMCW water quality projects (Tisl and Palas 1998) that producers would not adopt practices they believed would not be economically viable and that loss of momentum, such as when expected cost-share funds were lost, negatively impacted producer interest. Education efforts were also very important in establishing rapport with the landowners/producers and maintaining interest in the projects.

Targeted placement is a key element for ensuring that adoption of conservation practices results in desired water quality impacts. Efforts were made to utilize the best tools available at the time to target placement of conservation practices on the most vulnerable lands in both watersheds. Erosion and sediment delivery prediction models/equations were used in supporting this step. It is clear that many erosive landscapes are now much better protected in both watersheds as compared to conditions prior to the water quality projects. However, enhanced targeting tools now exist (e.g., Jha et al. 2010; Rabotyagov et al. 2010) that can be used to assess more efficient placement of conservation practices.

The use of structural conservation practices was a key component of the targeted conservation strategies. Adoption of structural conservation practices, especially terraces, grade stabilization structures, and water and sediment control basins, was stressed in both the SMCW and BRCW water quality projects. This was done to ensure relative permanence of conservation practices on crop lands, as opposed to relying more on conservation tillage or programs such as the CRP, which landowners and producers can change more easily. The use of structural practices was also needed to eliminate gulley problems that had developed on landscapes with extremely long slopes or consisted of very erosive soils that could not be fully protected with practices such as conservation tillage and contouring. However, periodic maintenance of terraces and other structural 
practices is required in order to make sure these practices continue to function properly, and eventually they will have to be reconstructed. Palas (2007) notes that some BRCW surface outlet terrace systems that were constructed as early as 1947 continue to function well.

The results of the studies also showed that it is possible for BMPs to have unintended negative water quality impacts. The increasing nitrate signals measured at the paired watershed sites during the SMCW Monitoring Project indicate the possibility that the tiled terrace systems may have increased the efficiency of routing leached nitrate to the stream system. The same phenomena occurred in the BRCW with similar increased terrace implementation. It is possible that other factors resulted in the increased nitrate levels, and it is important to keep in focus that the nitrate levels were still relatively low, especially in the SMCW. The small reduction in sediment loads at site SN1 in the SMCW also indicates that scouring of accumulated sediment in the stream channels may have been ongoing for an extended period after BMP implementation. As noted by Schilling et al. (n.d.), sediment export is directly related to stream discharge, and thus it is important to first reduce streamflow and stream power before expecting upland BMPs to result in major reductions in stream sediment loads.

The studies further revealed that more attention needs to be focused on timber management practices for watersheds with significant areas of woodland. The SMCW water quality projects described here were focused on BMP adoption on cropland. Later investigation revealed gulley erosion occurring in some woodland areas of the watershed, pointing to the need to include timber management in overall water quality planning for watersheds with high percentages of woodland. Progress was made in this regard for the BRCW water quality project (table 3 ).

Land-use change can affect conservation practice adoption and should be accounted for in watershed water quality projects. The decline in livestock production over the past two decades in the region, coupled with an increase in soybean production, has resulted in less use of contour strip cropping, buffer strip systems, and less perennials, such as alfalfa, in crop production systems in both watersheds. Palas (2007) also observed trends of declining CRP reenrollment in the
BRCW during the latter half of this decade (and shown in table 1), in spite of efforts to encourage continuous CRP sign-up (table $3)$, due to factors such as rental rates and commodity prices. Production trends resulting in less protection of cropland, with perennials or close-grown crops is a concern for both watersheds and could have negative water quality ramifications. Promotion of cropping systems that maintain perennials or close-grown crops or countering these trends with other conservation practices is an ongoing need in the region.

A critical need, related to targeting, is the buffering of highly vulnerable watershed locations. CRP acreage has declined in the BRCW as noted in the previous point. However, over $40 \%$ of the cropland directly adjacent to the stocked (with trout) stream channels was converted to CRP-type buffers by the end of the BRCW project, from cropland conversions that had occurred prior and during the BRCW Water Quality Project (Palas 2007). In contrast, Palas (2007) noted that none of the identified sinkholes had been properly buffered prior to the start of the project, and measurable progress was not made concerning protection of these vulnerable areas. Additional resources are needed to better protect sinkholes in the BRCW and the SMCW and in other watersheds in the region that are characterized by karst geology.

The existing water quality conditions for a specific set of watersheds should be taken into consideration before initiating paired watershed studies. The overall water quality of the SMCW and BRCW stream systems was considerably better than the majority of rivers and streams in Iowa (e.g., Schilling and Libra 2000; Libra et al. 2004). Starting at a point of relatively good water quality makes it difficult to determine true water quality changes.

It may take many years or even decades before water quality effects are detectable in response to BMP installation, indicating that much longer monitoring periods may be needed to document these long lag times, similar to findings by Schilling et al. (n.d.) and Meals et al. (2010). This is particularly true of streams with high baseflow, considerable preexisting sediment deposits in the stream channels, and/or excessive streambank and channel erosion.

The monitoring results further underscored the need to use smaller watersheds when trying to quantify the effects of conservation practices. The relatively large size of the study watersheds resulted in difficulty in detecting water quality changes. This was further exacerbated by the inability to control activities in the BRCW, where the installation of terraces and other conservation practices during the 10-year SMCW Monitoring Project study period likely reduced sediment loss in the BRCW and may have reduced the ability to statistically determine effects in the SMCW. Performing the paired watershed study using smaller areas, such as the watersheds described by King et al. (2008) that ranged in size from 389 to 454 ha (960 to $1,120 \mathrm{ac}$ ), would provide a higher probability of detecting changes.

A true baseline time period is needed of at least three to four years to obtain pre-BMP monitoring baseline data, as opposed to the approach used in this study. Concentrating on a more limited set of impairments would have also helped focus resources on the most important water quality impairments. Inclusion of more paired monitoring sites would have helped detect water quality changes and eliminate differences due to changes in precipitation, ambient conditions, or other non-BMP related factors.

Improved assessment of suspended sediment movement in watershed systems can be obtained by tracking specific sediment sources, such as those described by Simon and Klimetz (2008). Increased sampling frequency and/or event-based monitoring of suspended sediment may also be required for watersheds, such as the SMCW, where sediment concentrations can vary greatly during short time durations (i.e., less than one hour).

\section{Summary and Conclusions}

High priority has been placed on protecting northeast Iowa coldwater streams that are important natural resources supporting a variety of recreational activities such as trout fishing. Watershed-based water quality projects have been carried out for a number of these coldwater streams, which included intensive efforts to establish a variety of conservation practices on cropland. These include projects conducted for the SMCW and BRCW, which are both located in Clayton County, Iowa, and support recreational trout fishing. Water quality project strategies in both watersheds focused on securing sufficient cost-share funds and 
multiple agency collaboration to support the resources needed for implementing structural conservation practices and other desired BMPs. Landowner/producer participation rates were high in both projects, reflecting the strong historical conservation ethic in the region and committed efforts of project coordinators and agency personnel to establish effective relationships with landowners and producers and to develop cost-effective pollution mitigation strategies on a farm-byfarm basis. Sediment delivery to the SMCW stream system was estimated to decline by 50\% during 1991 to 1998 in response to the conservation practices installed in the watershed, which was roughly equal to $3,900 \mathrm{t} \mathrm{y}^{-1}$ $\left(4,300 \mathrm{tn} \mathrm{yr}^{-1}\right)$. Soil loss reductions of about $2,800 \mathrm{t} \mathrm{y}^{-1}\left(3,090 \mathrm{tn}_{\mathrm{yr}^{-1}}\right)$ were estimated for the BRCW due to practices installed there during 2002 to 2007.

During 1992 to 2001, monitoring was conducted for discharge, total suspended solids, turbidity, and $\mathrm{NO}_{\mathrm{x}}-\mathrm{N}$. Statistical analysis using a pre/post model for the downstream site (SN1) indicated that discharge increased $8 \%$, turbidity declined $41 \%$, sediment declined $7 \%$, and $\mathrm{NO}_{\mathrm{x}}-\mathrm{N}$ increased $15 \%$. The gradual change model results were similar, with predicted increases of $12 \%$ and $39 \%$ for discharge and $\mathrm{NO}_{\mathrm{x}}-\mathrm{N}$, respectively, a decrease in turbidity of $46 \%$, and no statistically significant change for total suspended solids. The weak sediment reductions were inconsistent with previously predicted sediment reductions, indicating that continued scouring of in-stream sediment likely occurred and that reductions in stream discharge may be required in the SMCW and similar stream systems in order for significant sediment load decreases to occur. The increased $\mathrm{NO}_{\mathrm{x}}-\mathrm{N}$ levels were also unexpected and may have resulted from increased transport due to the large influx of tile terraces during 1988 to 1999 in the SMCW. Fish surveys indicate that natural trout reproduction occurs in the Bloody Run Creek and that overall conditions required for supporting trout fisheries have improved in both streams. Other important lessons learned in this study include (1) committed project coordinators, agency collaborators, and landowners/producers are all needed for successful water quality projects; (2) smaller watershed areas should be used in paired studies; and (3) long-term monitoring (decadal scale) may be required to detect meaningful changes in water quality in response to BMP implementation.

\section{Acknowledgements}

This research was funded in part from support provided by the USDA Cooperative State Research, Extension, and Education Service (Project No. 20045113003120). Many other agencies provided support in terms of personnel and/or funding for establishing conservation practices or by conducting water quality assessments as described in the text, and we acknowledge them once again here: the IDNR, the IDALS DSC, Iowa State University Extension, Clayton SWCD, the USDA NRCS, the USDA Farm Service Agency, the University of Iowa Hygienic Laboratory, and the US Geological Survey. Finally, we acknowledge the landowners and producers who live and work in the Sny Magill Creek and Bloody Run Creek watersheds. Their cooperative spirit and commitment to conservation is truly exemplary.

\section{References}

Babcock, B.A., T.A. Hurley, and J. Wu. 1998. The Environmental Effects of Freedom to Farm. Selected paper presented at the 1998 American Agricultural Economics Association Annual Meeting, Salt Lake City, Utah. http://ageconsearch.umn.edu/ bitstream/20823/1/spbabc01.pdf.

Clausen, J.C., and J. Spooner. 1993. Paired Watershed Study Design. EPA-841-F-93-009. Washington DC: Office of Water, US Environmental Protection Agency.

Duriancik, L.F., D. Bucks, J.P. Dobrowski, T. Drewes, S.D Eckles, L. Jolley, R.L. Kellogg, D. Lund, J.R. Makuch, M.P. O'Neill, C.A. Rewa, M.R. Walbridge, R. Parry, and M.A. Weltz. 2008. The first five years of the Conservation Effects Assessment Project. Journal of Soil and Water Conservation 63(6):185A-197A, doi:10.2489/jswc.63.6.185A.

Fields, C. 2004. The Sny Magill Watershed National Monitoring Program: A ten-year study on best management practices and their effects on water quality. In NWQEP Notes: The NCSU Water Quality Group Newsletter. Number 113. Raleigh, NC: North Carolina State University.

Fields, C.L., H. Liu, R.J. Langel, L.S. Seigley,T.F.Wilton, G.M. Nalley, M.D. Schueller, M.W. Birmingham, G. Wunder, V. Polton, V. Sterner, J. Tial, and E. Palas. 2005. Sny Magill Nonpoint Source Pollution Monitoring Project: Final Report. Iowa Department of Natural Resources, Geological Survey Bureau Technical Information Series 48, Iowa City, IA. http://www.igsb.uiowa. edu/webapps/gsbpubs/pdf/TIS-48.pdf.

Griffith, G.E., J.M. Omernik, T.F. Wilton, and S.M. Pierson. 1994. Ecoregions and subregions of Iowa - a framework for water quality assessment and management. The Journal of the Iowa Academy of Science 101(1):5-13.

IDNR (Iowa Department of Natural Resources). 2007. A Success Story The Rebirth of Iowa's Trout Streams. Des Moines, IA: Iowa Department of Natural Resources. http://www.iowadnr.gov/water/nonpoint/files/trout.pdf.
Jha, M.K., K.E. Schilling, P.W. Gassman, and C.F. Wolter. 2010. Targeting land-use change for nitrate-nitrogen load reductions in an agricultural watershed. Journal of Soil and Water Conservation 65(6):342-352, doi:10.2489/jswc.65.6.342.

Kalishek, B. 2005. Iowa's trout hook anglers \& conservationists. INHF Quarterly Magazine (Spring edition). Des Moines, IA: Iowa Natural Heritage Foundation. http://www.inhf. org/magazines/mag_archive/2005_currentmag.htm.

King, K.W., P.C. Smiley Jr., B.J. Baker, and N.R. Fausey. 2008. Validation of paired watersheds for assessing conservation practices in the Upper Big Walnut Creek watershed, Ohio. Journal of Soil and Water Conservation 63(6):380-395, doi:10.2489/jswc.63.6.380.

Libra, R.D., C.F. Wolter, and R.J. Langel. 2004. Nitrogen and phosphorus budgets for Iowa and Iowa watersheds. Technical Information Series 47. Iowa City, Iowa: Iowa Department of Natural Resources-Geological Survey. http://www.iowadnr.gov/water/nutrients/files/nbfull.pdf. Lombardo, L.A., G.A. Grawbow, J. Spooner, D.E. Line, D.L. Osmond, and G.D.Jennings. 2000. Section 319 Nonpoint Source National Monitoring Program: Successes and Recommendations. Raleigh, NC: NCSU Water Quality Group, Agricultural and Biological Engineering Department, North Carolina Cooperative Extension Service, North Carolina University. http://www.bae. ncsu.edu/programs/extension/wqg/319monitoring/ doc/nmp_successes.pdf.

Lyons, J., L. Wang, and T.D. Simonson. 1996. Development and validation of an index of biotic integrity for coldwater streams in Wisconsin: North American Journal of Fisheries Management 16:241-256.

Meals, D.W., S.A. Dressing, and T.E. Davenport. 2010. Lag Time in Water Quality Response to Best Management Practices: A Review Journal of Environmental Quality 39:85-96, doi:10.2134/jeq2009.0108.

Mundahl, N.D., and T.P. Simon. 1999. Development and application of an index of biotic integrity for coldwater streams of the upper Midwestern United States. In Assessing the Sustainability and Biological Integrity of Water Resources using Fish Communities, ed. T.P. Simon, 383-415. Boca Raton, FL: CRC Press.

Palas, E. 2007. Bloody Run watershed project: Final report. Elkader, IA: Clayton Soil and Water Conservation District, Iowa Department of Agriculture and Land Stewardship.

Rabotyagov, S.S., M.K. Jha, and T. Campbell. 2010. Impact of crop rotations on optimal selection of conservation practices for water quality protection. Journal of Soil and Water Conservation 65(6):369-380, doi:10.2489/jswc.65.6.369.

Renard, K.G., G.R. Foster, G.A. Weesies, D.K. McCool, and D.C. Yoder. 1997. Predicting Soil Erosion by Water: A Guide to Conservation Planning with the Revised Universal Soil Loss Equation (Rusle). USDA Agricultural Handbook No. 703. 
Richardson, C.W., D.A. Bucks, and E.J. Sadler. 2008. The Conservation Effects Assessment Project benchmark watersheds: Synthesis of preliminary findings. Journal of Soil and Water Conservation 63(6):590-604, doi:10.2489/jswc.63.6.590.

Schilling, K., T. Isenhart, J. Palmer, and C.Wolter. nd. Detecting changes in suspended sediment transport with land cover change in paired agricultural watersheds. Journal of the American Water Resources Association (submitted).

Schilling, K.E., and R.D. Libra. 2000. The relationship of nitrate concentrations in streams to row crop land use in Iowa. Journal of Environmental Quality 29(6):1846-1851.

Schilling, K.E., M.D. Tomer, P.W. Gassman, C.L. Kling, T.M. Isenhart, T.B. Moorman, W.W. Simpkins, and C.F. Wolter. 2007. A tale of three watersheds: Nonpoint source pollution and conservation practices across Iowa. CHOICES: The Magazine of Food, Farm, and Resource Issues. American Agricultural Economics Association 22(2):87-95.

Simon, A., and L. Klimetz. 2008. Relative magnitude and sources of sediment in benchmark watersheds of the Conservation Effects Assessment Project. Journal of Soil and Water Conservation 63(6):504-522, doi:10.2489/jswc.63.6.504.

Spooner, J., R.P. Maas, S.A. Dressing, M.D. Smolen, and F.J. Humenik. 1985. Appropriate designs for documenting water quality improvements from agricultural NPS control programs. EPA 440/5-85-001. In Perspectives on Nonpoint Source Pollution, Proceedings of a National Conference, 30-34. May 19-22, Kansas City, MO. Washington, DC.

Tisl, J., and E. Palas. 1998. Sny Magill Creek Watershed Project, Clayton County, Iowa: Final Report. Elkader, IA: Clayton Soil and Water Conservation District, Iowa Department of Agriculture and Land Stewardship.

USDA NRCS (Natural Resources Conservation Service). 1998. Erosion and sediment delivery. Field Office Technical Guide Notice No. IA-198. Des Moines, IA: USDA Natural Resources Conservation Service.

USDA NRCS. 2008. Conservation Effects Assessment Project (CEAP).Washington DC: USDA NRCS. http:// www.nrcs.usda.gov/TECHNICAL/NRI/ceap/.

USEPA (US Environmental Protection Agency). 2009. Clean Waters Act Section 319: Laws, regulations, Treaties. Washington, DC: US Environmental Protection Agency. http://www.epa.gov/nps/cwact.html.

Wischmeier, W.H., and D.D. Smith. 1978. Predicting Rainfall Erosion Losses: A Guide to Conservation Planning. Agriculture Handbook No. 537. Washington DC: USDA. http://topsoil.nserl.purdue.edu/usle/AH_537.pdf. 